\title{
PALYNOLOGY AND ARCHAEOLOGY OF LATE VISTULIAN AND EARLY HOLOCENE SITES IN LUBUSKIE LAKE DISTRICT, WESTERN POLAND
}

\author{
Iwona Okuniewska-Nowaczyk, Iwona Sobkowiak-Tabaka \\ Polish Academy of Sciences, Institute of Archaeology and Ethnology, Centre for Prehistoric and Medieval \\ Research, ul. Rubiez 46, 61-612 Poznań, Poland, e-mail: iwona.okuniewska@iaepan.poznan.pl, \\ iwona.sobkowiak@iaepan.poznan.pl
}

\begin{abstract}
The Lubuskie Lake District played an important part in recolonisation of the Polish Plain due to its location and the character of the terrain. Despite that, it is and especially its northern part, poorly explored regarding both history of Late Glacial and early Holocene settlements, and the natural environment. The paper presents results of multidisciplinary research in this area. The most spectacular discoveries were connected with remains of settlements of the Hamburgian culture societies at Myszęcin - currently the richest site of this culture over the entire North European Plain. In the vicinity of this site several Late Palaeolithic and Mesolithic settlements of varied functions were recorded. First palynological records came from the Younger Dryas sediments in this area. In a log with a palynological spectrum comprising Younger Dryas and the beginning of the Holocene, a charcoal dust was found and it could indicate human activity as humans lived at a lake shore. An important complement to the image of the Late Glacial settlement at the Lubuskie Lake District was provided by the research near Lubrza that resulted in data regarding settlements of the Federmesser and Świderian culture societies. This region was not typical in a palynological spectrum of deposits during Allerød but also indicated highly diversified thickness of basal peat in a small area.
\end{abstract}

Key words: Lubuskie Lake District, Late Vistulian, Early Holocene, palynology, archaeology.

Manuscript received 2 September 2013, accepted 15 May 2014

\section{INTRODUCTION}

Areas which have been scarcely explored are particularly interesting for multidisciplinary research. The Lubuskie Lake District and especially its northern part is among such regions. There have been partial studies of both the history of the Late Glacial and early Holocene settlements (Kobusiewicz, 1999; Sobkowiak-Tabaka, 2011) and the natural environment (Okuniewska-Nowaczyk, 2005). Palynological research was conducted in Sulechów area at Pomorsko and the sites at Chwalim, Liny, Smolno Wielkie and Wojnowo, all described by archaeologists as the Wojnowo region (Fig. 1).

Regular excavation have been carried out incessantly in the Wojnowo region since 1968 by Michał Kobusiewicz on behalf of the then Institute of Material Culture History (at present Institute of Archaeology and Ethnology) of the Polish Academy of Sciences and eleven archaeological sites were examined (Fig. 1). They were mainly camps of societies from the earliest prehistorical periods, beginning with the first human groups that were the reindeer hunters, who recolonized the area of the Polish Plain at the termination of the Pleistocene, through the settlements of hunter-gatherers in the Middle Stone Age, until the early Lausatian culture of the Bronze Age (Kobusiewicz, 1999).
In recent years, a number of Late Palaeolithic and Early Mesolithic archaeological sites have been discovered and investigated by excavations in the northern part of the $\mathrm{Lu}-$ buskie Lake District (Fig. 1). Among those, only the site 42 at Lubrza (Kabaciński, Sobkowiak-Tabaka, 2011a-c) enabled multidisciplinary studies that permitted multi-aspect analysis of the settlement, beginning with flint inventories, through radiocarbon dating up to reconstruction of natural environment which, to a large extent, enabled development of the settlements.

Among the crucial aims of the research carried through by both geoscientists and humanists is direct correlation between transformations of natural environment and diversified archaeological evidence.

\section{STUDY AREA}

The Lubuskie Lake District is located between the Gorzów Basin in the north, the Middle Oder Valley in the south and the topographic low used by the Obra River in the east (Kondracki, 2009). The varied terrain of this area was formed by the Scandinavian ice sheet during its advance and retreat, including also a glaciofluvial activity. The plateaus and ice-marginal streamways created latitudinal land strips, sep- 


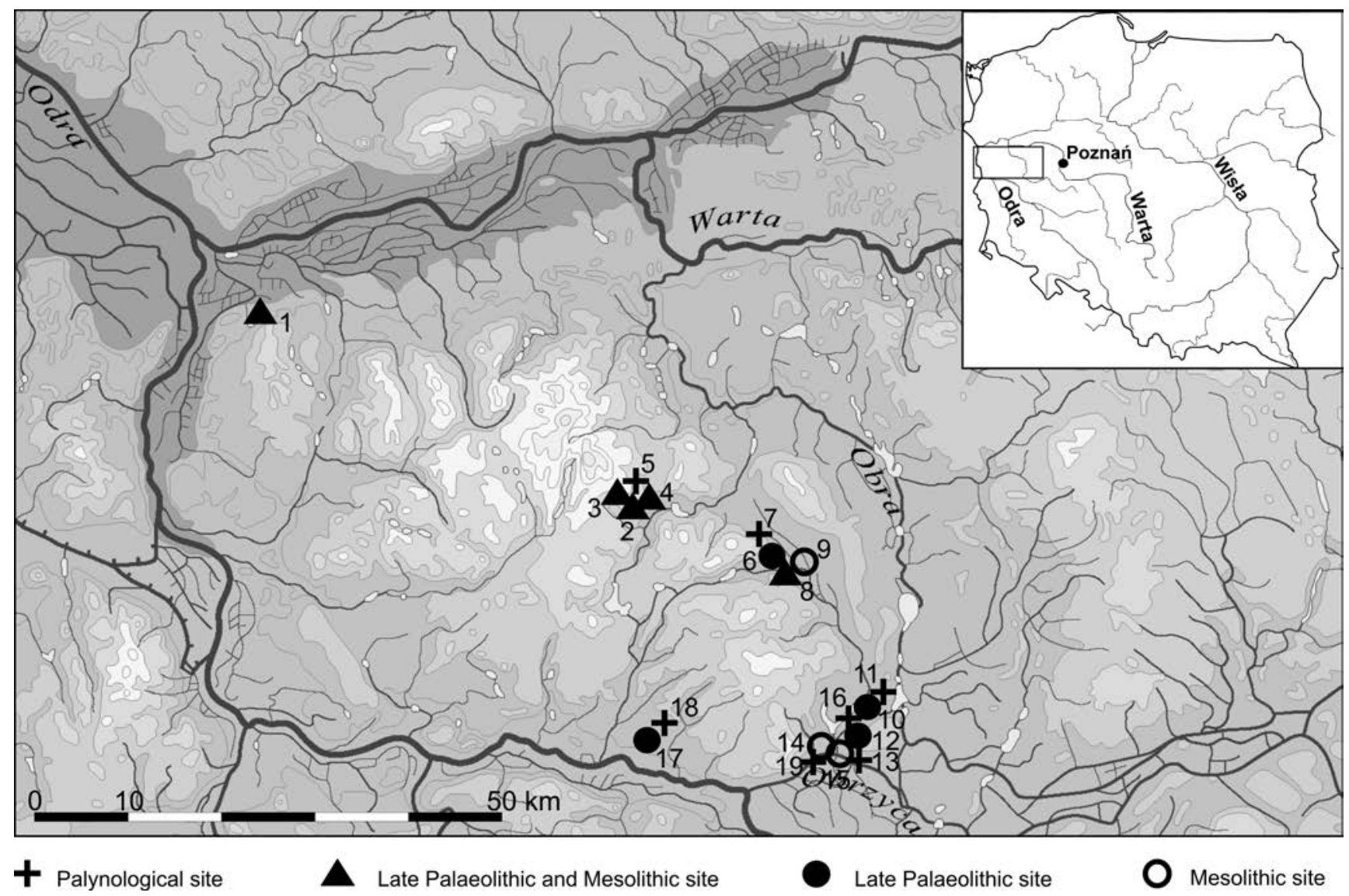

Fig. 1. Palynological and important Late Palaeolithic and Mesolithic sites in the Lubuskie Lake District (drawing by P. Szejnoga, A. Tabaka). 1 - Ośno Lubuskie, site 7 (Kabaciński and Sobkowiak-Tabaka, 2010a, b), 2 - Lubrza, site 42 (Kabaciński and Sobkowiak-Tabaka 2011a, b), 3 - Lubrza, site 11 (Kabaciński and Sobkowiak-Tabaka, 2011a, b), 4 - Lubrza, site 10 (Sobkowiak-Tabaka, 2013), 5 - Lubrza (Okuniewska-Nowaczyk, 2011a), 6 - Myszęcin, site 19 (Kabaciński and Sobkowiak-Tabaka, 2012), 7 - Myszęcin (OkuniewskaNowaczyk, 2013, 8 - Wilenko, site 16 (Sobkowiak-Tabaka, 2013), 9 - Wilenko, site 13 (Sobkowiak-Tabaka, 2013), 10 - Liny, site 1 (Kobusiewicz, 1973), 11 - Liny (Kobusiewicz et al. (1987), 12 - Wojnowo, sites 'a' and 2 (Kobusiewicz and Kabaciński, 1988; Kobusiewicz, 1999), 13 - Wojnowo (Okuniewska-Nowaczyk, unpubl.), 14 - Wojnowo, site 3 (Bobrowski, 1996), 15 - Chwalim, site 1 (Kobusiewicz and Kabaciński, 1993), 16 - Chwalim (Wasylikowa, 1993), 17 - Pomorsko, site 1 (Kobusiewicz et al., 1987), 18 - Pomorsko (Tobolski, 1972 in Nowaczyk 1976; Okuniewska-Nowaczyk, unpubl.), 19 - Smolno Wielkie (Okuniewska-Nowaczyk, unpubl.).

arated by longitudinal river gorges. Due to its landscape, this area has been attractive for the Late Glacial societies in terms of camp location and convenient hunting territories.

In 1960s interdisciplinary studies were carried out in the area of Sulechów (sites: Chwalim, Liny, Pomorsko, Smolno Wielkie, Wojnowo), located in the Warsaw-Berlin Pradolina (Warsaw-Berlin ice-marginal streamway); as well as in the Kargowa Basin and the Krosno Odrzańskie reach of the Middle Oder Valley.

The Pomorsko site underwent a mutli-aspect analysis: geology done by Nowaczyk $(1974,1976,1978,1979)$ and Nowaczyk et al. (1985) (Fig. 2), palynology by Tobolski (1972 in: Nowaczyk, 1974, 1976) (Fig. 3), malacology by Urbański (in: Nowaczyk, 1976), Alexandrowicz (1980) and Alexandrowicz and Nowaczyk (1982), archaeology by Kobusiewicz (1973, 1996, 1999 and in: Nowaczyk, 1976) and Kobusiewicz and Kabaciński (1991), pedology by Kowalkowski (1977a, b) and radiocarbon dating (Pazdur et al., 1979; Nowaczyk et al., 1985).

Archaeological and environmental studies were completed for the Liny site (Kobusiewicz et al., 1987) and Chwalim (Kobusiewicz and Kabaciński, 1993). K. Wasy- likowa (1993) dedicated an entire extensive chapter of Chwalim's monograph to the history of vegetation at the site. Other chapters also included results of a dendrological and malacological analysis conducted by A. Dzięczkowski (1993a, b).

A monograph of the Wojnowo site (Kobusiewicz et al., in press) is being prepared for publication.

The area of Jordanów-Niesulice tunnel valley is the centre of investigation at present. This area is located to the west of the Lubrza-Lugów-Rzeczyca end moraines of the Poznań phase of the last Scandinavian glaciation (Kozarski, 1995; Żynda, 1963, 1967).

\section{STAGE OF RESEARCH}

Two stages of research can be distinguished in development of Late Palaeolithic and Mesolithic settlements at the Lubuskie Lake District. The earlier one, was carried out in the Wojnowo region and the more recent one was connected with rescue archaeological excavations connected with construction of highways and ring roads. 
A

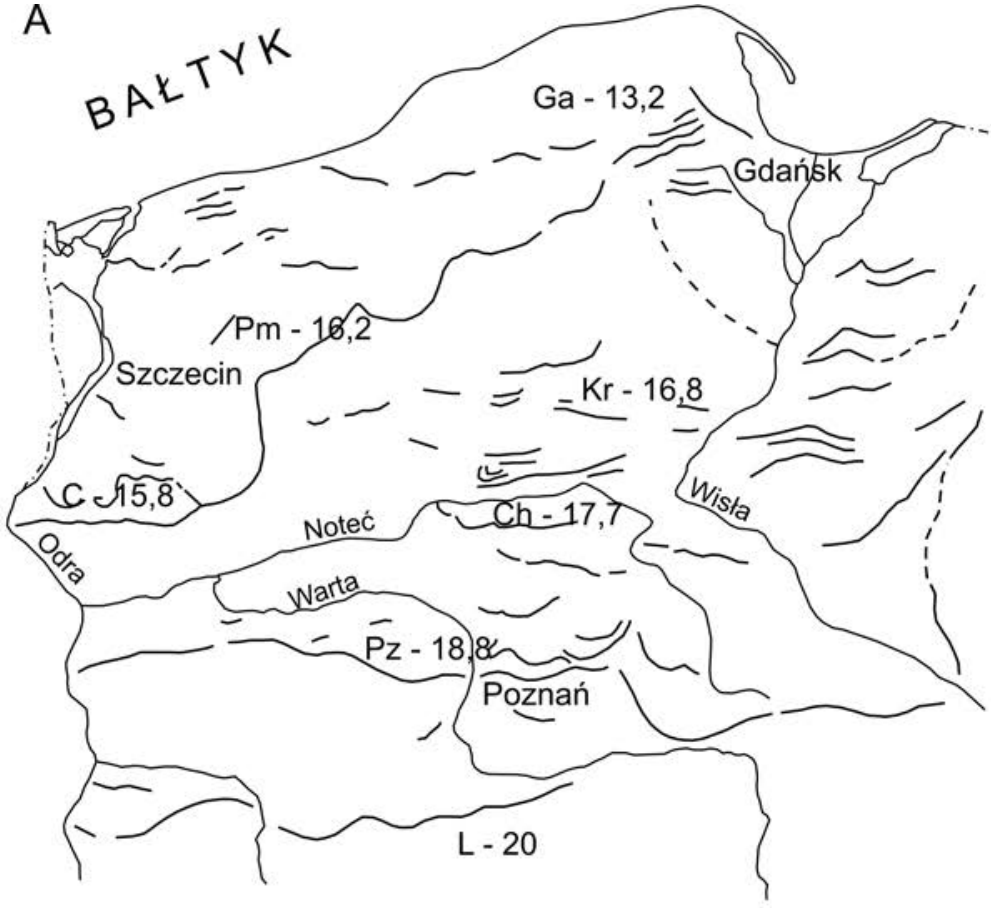

Ga - Gardno phase - 13200 yrs BP C - Chojno subphase -15800 yrs BP $\mathrm{Pm}$ - Pomeranian phase -16200 yrs BP $\mathrm{Kr}$ - Krajna subphase - 16800 yrs BP Ch - Chodzież subphase -17700 yrs BP Ch - Chodziez subphase - 17700 yrs $\mathrm{BP}$
$\mathrm{Pz}$ - Poznań phase -18800 yrs BP L - Leszno phase - 20000 yrs BP

B

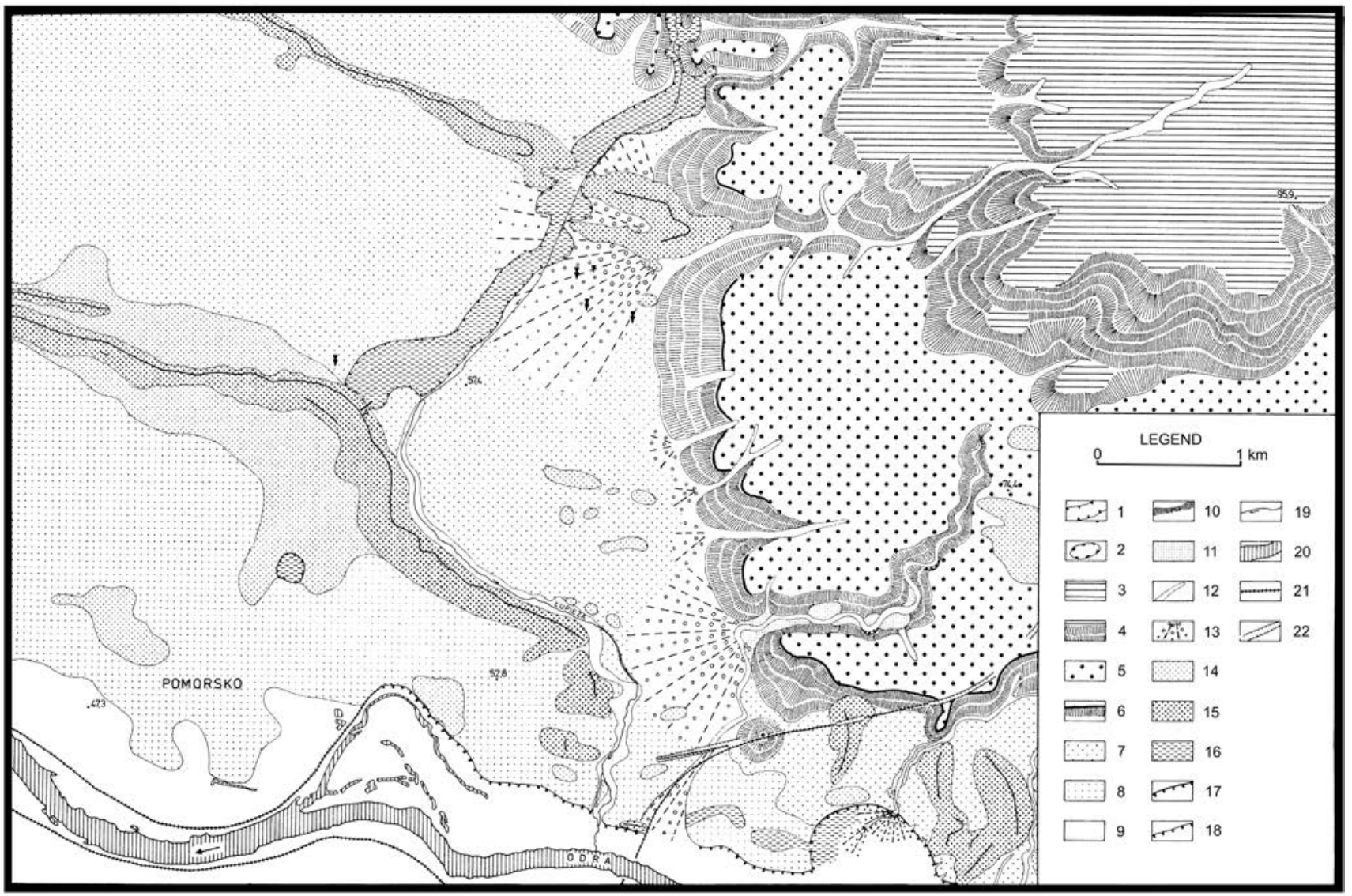

1 - glacial troughs 2 - dead ice hollows 3 - flat morainic plateau 4 - plateau slopes 5 - Sulechów sandr younger than the Leszno phase 6 - pradolina slopes 7 - the first pradolina terrace - the Poznań phase 8 - the third pradolina terrace 9 - the fourth terrace - the Odra valley bottom

10 - slopes of erosion-denudation valleys 11 - terraces within erosion-denudation valleys 12 - bottoms of erosion-denudation valleys 13 - aluvial cones 14 - dunes 15 - eolian cover sands 16 - biogenic accumulation plains 17 - erosion cuts with scarps ower $5 \mathrm{~m}$. high 18 - erosion cuts with scarps 2 - $3 \mathrm{~m}$. high 19 - small streams 20 - rivers and abandoned channels 21 - anthropogenic dikes 22 - anthropogenic excavations

Fig. 2. Pomorsko. A - phases and subphases of the Vistulian Glaciation after Kozarski (1995), B - geomorphological map showing the sourroundings of Pomorsko after Nowaczyk (1979). 


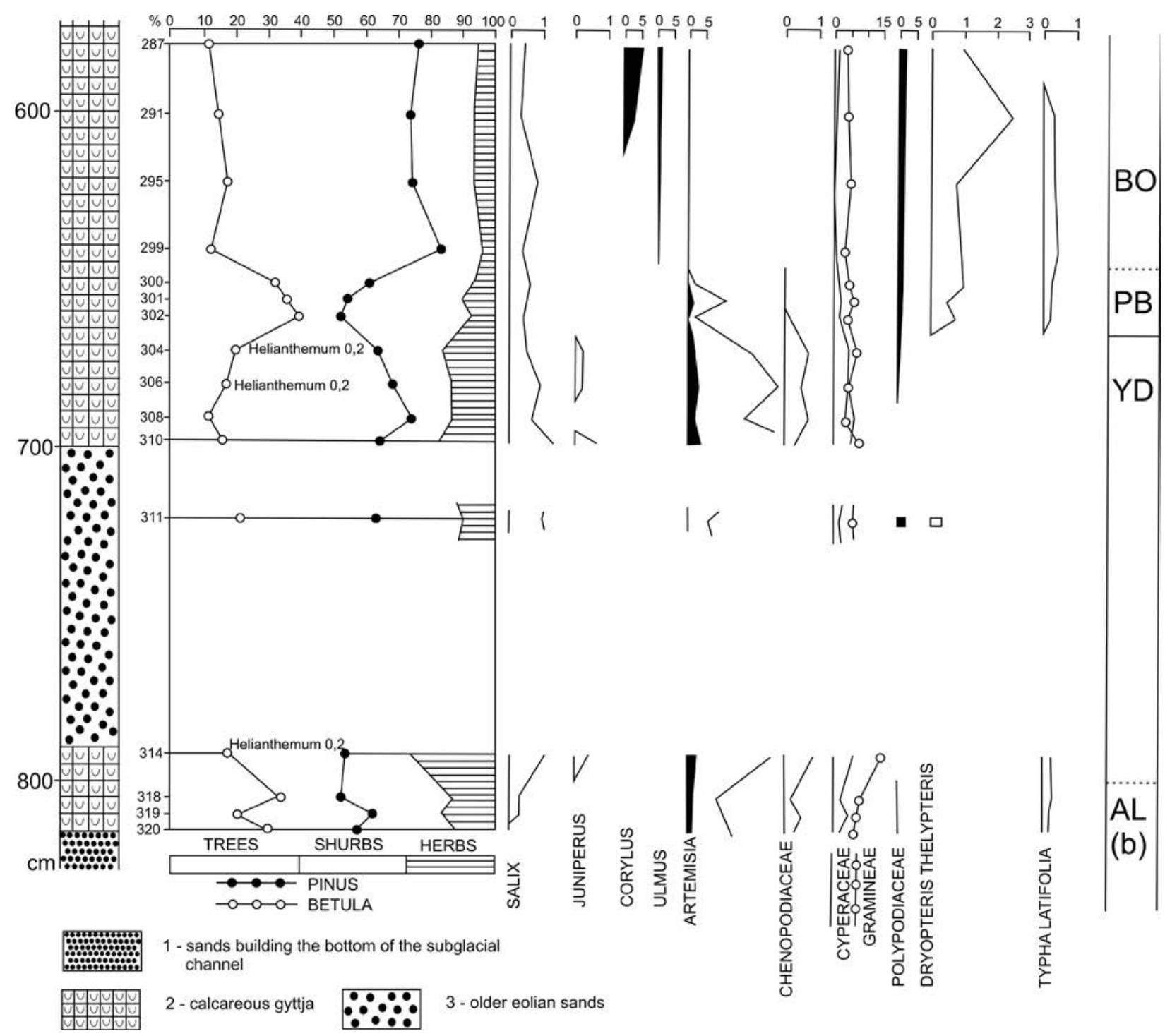

Fig. 3. Pomorsko. A simplified pollen diagram of organic deposits filling a bottom of a subglacial tunnel valley after Tobolski (1972, in: Nowaczyk, 1976).

\section{Research in the southern part of the Lubuskie Lake District}

\section{Wojnowo region}

The region is located ca. 100 kilometres to the west of Poznań, at crossing of natural communication routes, in a drainage basin of two small rivers (Gniła Obra and Kopanica), limited in the south by a northern edge of the Warsaw-Berlin ice-marginal streamway. Archaeological research in the Wojnowo region was initiated in 1920s by Otto Dobrint, a German amateur archaeologist and a teacher from Wielka Wieś. We owe him our knowledge about the Late Palaeolithic sites at Chwalim, Liny, Wojnowo and Smolno Wielkie. He also carried out exploratory research in the vicinity of Babimost and Kargowa. Among the sites mentioned earlier, the most prominent was the Hamburgian culture site at Liny, from which three finds were published in a monograph by Rust (1943). The notes of Dobrint inspired a wide scope of exploratory research in this area, resulting in location of the Liny site, as well as other Late Palaeolithic and Mesolithic camps (Kobusiewicz, 1999).

The post-second world war history of research on the Wojnowo region dates back to the end of 1960s. The studies resulted in excavation of 11 Palaeolithic, Mesolithic and para-Neolithic sites at Smolno Wielkie, Liny, Pomorsko, Wojnowo and Chwalim, and were fragmentarily published (Kobusiewicz et al., 1987; Kobusiewicz and Kabaciński, 1992, 1993). Simultaneously, surface survey and test excavations carried out in the valleys of the Gniła Obra River and the Obra River and along the edge of the Warsaw-Berlin ice-marginal streamway resulted in discovering 24 sites from the Early and Middle Stone Age. A research in the Wojnowo region has been conducted in cooperation with J. Bower from Iowa State University in Ames, Iowa, USA, since 1984 (Kobusiewicz, 1996). The aim of the research was to compare cultural development of the Late Palaeolithic and Mesolithic hunter-gatherers of the North European Plain and the 
Table 1

Wojnowo, site 2. Radiocarbon dating comparison: uncorrected age in years BP and after calibration with the program OxCal v. 4.2.3 (Bronk Ramsey, Lee 2013); application available on https://c14.arch.ox.ac.uk/oxcal/OxCal.html

\begin{tabular}{|c|c|c|c|c|c|}
\hline \multirow{2}{*}{ Site } & \multirow{2}{*}{ Material } & \multirow{2}{*}{ Lab. no. } & \multirow{2}{*}{${ }^{14} \mathrm{C} \mathrm{BP} *$} & \multicolumn{2}{|c|}{ Age $\mathrm{BC} / \mathrm{AD}$} \\
\hline & & & & $68.2 \%$ & $95.4 \%$ \\
\hline Wo 2 & charcoal & Gd-2976 & $9,880 \pm 170$ & $9,762-9,202$ & $10,046-8,833$ \\
\hline Wo 2 & charcoal & Gd-2975 & $10,130 \pm 120$ & $10,049(56.4 \%)-9,650$ & $10,277-9,314$ \\
\hline Wo 2 & charcoal & Gd-5045 & $10,260 \pm 100$ & $10,218(63.3 \%)-9824$ & $10,562-9,558$ \\
\hline Wo 2 & charcoal & Gd-6096 & $10,340 \pm 130$ & $10,472(67.7 \%)-10,013$ & $10,633-9,692$ \\
\hline Wo 2 & charcoal & Gd-2577 & $12,540 \pm 120$ & $13,148-12,578$ & $13,252-12,272$ \\
\hline
\end{tabular}

*According to Kobusiewicz (1999)

societies from the Palaeo-Indian Stage of the Archaic Stage in the middle-eastern United States, who lived in a similar natural environment (Bower and Kobusiewicz, 1988, 2002).

\section{Liny}

The site 1 at Liny is the earliest explored Polish site of the Hamburgian culture societies that recolonized the Polish Plain after deglaciation of the area. It was discovered during surface surveys in 1928 by Dobrint and it was investigated by him during excavations in 1940. In late 1960s the site was discovered again and explored during three consecutive seasons by Kobusiewicz (1973).

The site was located in sand and gravel outwash terrace at the northern edge of the Lake Małe Liny, at an western edge of a ditch linking this reservoir with the Lake Wachabno. Both lakes occurred at the south-western end of the extension of the Nowy Tomyśl outwash, cut with watercourses that emerged in the Leszno Phase of the last Scandinavian glaciation (Fig. 2). As a result of the research 932 artefacts made of Cretaceous erratic flint were found and connected with a settlement of the Hamburgian culture societies (Kobusiewicz, 1975).

\section{Wojnowo, site ' $a$ '}

The site was located at the northern end of Wojnowo village or more precisely, at a south-eastern shore of the southern end of the Lake Babimojskie-Tuchola, near the isthmus between the Lake Wojnowskie and the Lake Babimojskie (Kobusiewicz and Kabaciński, 1988; Figs 1, 4). The artefacts were found at the top of the sand and gravel terrace, carved out by a ribbon lake in an outwash younger than the Poznań Phase of the last glaciation (Nowaczyk, 1976). A number of accumulations of flint were found at the site, with two of them being later explored. As many as 10,000 items of flint artefacts were deposited to $0,8 \mathrm{~m}$ depth but without any preserved stratigraphic sequence.

All artefacts were made of Cretaceous erratic flint. Technological and typological structure of materials indicated that the inventory could be connected with societies of a technocomplex with Pedunculated Tanged Points that occupied the Polish Plain, mainly during the Younger Dryas.

\section{Wojnowo, site 2}

The site was located at a sandy gravel shore of the Lake Wojnowskie, near a narrow isthmus that separated it from the
Lake Babimojskie-Tuchola (Kobusiewicz, 1999; Figs 1, 4). Just like at the site Wojnowo ' $a$ ', flint artefacts had no preserved stratigraphic sequence in the soil horizons $A$ and $B$ to a depth of $1 \mathrm{~m}$. The accumulation, ca. $13 \mathrm{~m}$ in diameter, formed an irregular oval in which 3 pits were distinguished, $30-70 \mathrm{~cm}$ deep, with pinkish tinge infilling caused by presence of hematite. In the north-western part of the site there was a round hearth, ca. $125 \mathrm{~cm}$ in diameter, built of burnt rocks. From the explored area of $77 \mathrm{~m}^{2} \mathrm{ca} .3000$ flint artefacts were excavated. These were connected with a settlement of the societies of a Pedunculated Tanged Points Technocomplex (Kobusiewicz, 1999). Charcoal from a peat bog adjacent to the site was radiocarbon dated (Table 1).

\section{Pomorsko}

The site is located at a top of a high dune ridge being a part of a dune several kilometres long, which is adjacent to a reservoir that was created by melting of a buried dead ice

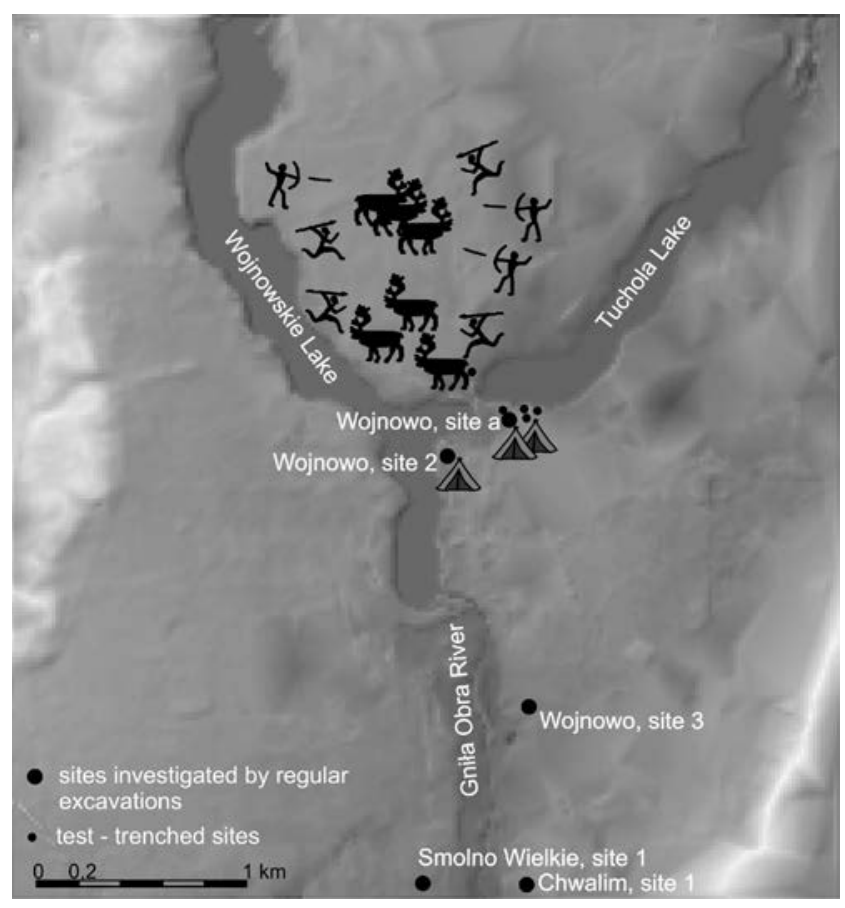

Fig. 4. Wojnowo. Strategic location of the Late Palaeolithic and Mesolithic sites at Lake Tuchola and Lake Wojnowskie, Digital Terrain Model (N-33-140-D-a-3) after Kobusiewicz (2008), modified. 
Table 2

Pomorsko, site 1. Radiocarbon dating comparison: uncorrected age in years BP and after calibration with the program OxCal v. 4.2.3 (Bronk Ramsey, Lee 2013); application available on https://c14.arch.ox.ac.uk/oxcal/OxCal.html

\begin{tabular}{|l|c|c|c|c|c|c|}
\hline \multirow{2}{*}{ Site } & Place & Material & Lab. no. & ${ }^{14}$ C BP* & \multicolumn{2}{|c|}{ Age BC/AD } \\
\cline { 4 - 6 } & & & & & $68.2 \%$ \\
\hline Pomorsko 1; Pr no. 2 & hearth & charcoal & Gd-2700 & $7,330 \pm 100$ & $6,260(60.7 . \%)-6,070$ & $6400-6020$ \\
\hline Pomorsko 1; Pr no. 10 & hearth & charcoal & Gd-2704 & $7,740 \pm 100$ & $6,656-6,464$ & $7021-6412$ \\
\hline Pomorsko 1; Pr no. 9 & outside hearth & charcoal? & Gd-2701 & $6,660 \pm 90$ & $5,646-5,512$ \\
\hline
\end{tabular}

*According to Kobusiewicz (1999)

(Figs 1,2). The dune occurred in a ravine of the 1 st and $3 \mathrm{rd}$ terraces of the Warsaw-Berlin ice-marginal streamway (Nowaczyk, 1976). The area near Pomorsko has been examined in detail since 1966 and flint pieces with traces of processing by humans were found on a proximal slope of a dune (Nowaczyk, 1976). The artefacts were handed over to M. Kobusiewicz, who conducted detailed and specialized archaeological research in 1970-1971.

Unfortunately, plentiful remains of the Palaeolithic settlement were covered by equally abundant remains of a later Mesolithic settlement and it has been virtually impossible to differentiate flint inventories taxonomically base on a stratigraphic sequence or a type of material. The only criterion used to differentiate the artefacts was a typology of flint tools and cores (Kobusiewicz, 1999).

The later, Mesolithic stage of the settlement in this area (Table 2) was correlated with the Atlantic Period, basing on radiocarbon dating of charcoal in a shallow pithouse with hearths inside. Burnt animal and human bones were found in the north-western and middle part of the site (Kobusiewicz and Kabaciński, 1991).

\section{Chwalim}

The site was located at a sand and gravel terrace, at an edge of a peat-filled oxbow lake (Schild, 1993). The flint inventory with 226 items was excavated from the lower organic layers adjacent to the edge of the sand and gravel terrace of the Gniła Obra River. Apart from the flint artefacts, bones of a deer (Cervus elaphus), an elk (Alces alces) and a bison (Bison bonasus) were found. Radiocarbon dating (Table 3 ) and palynological research of K. Wasylikowa revealed that the settlement could have been connected with the middle Preboreal Period (Kobusiewicz and Kabaciński, 1993).

A history of palynological research dates back to 1970s. It was then that Tobolski (1972, in: Nowaczyk, 1976) completed an analysis of deposits from the site at Pomorsko. He proved that deposition of organic deposits began in the pine phase of Allerød, however, due to some interference a palynological spectrum of the Late Vistulian is fragmentary only (Fig. 3; Table 4). When archaeologists were invited to participate in research, the region became a subject of interest to geoscien- tists once again. Studies were completed for the following sites: Liny (Kobusiewicz et al., 1987), Chwalim (Kobusiewicz and Kabaciński, 1993), Wojnowo (Kobusiewicz and Kabaciński, 1988, 1992; Bobrowski, 1996; Bobrowski et al., 2013; Okuniewska-Nowaczyk, unpubl.), Smolno Wielkie (Okuniewska-Nowaczyk, unpubl.). Unfortunately, they did not encompass the entire uninterrupted time scope of the Late Vistulian and the Holocene (Table 4). A history of the transition of the Late Vistulian vegetation was recorded in deposits of different origin: in sand with detritus, in gyttja and peat of varied thickness. The earliest deposits - from the pre-Allerød period - were found at Liny (Kobusiewicz et al., 1987). Nature of deposition, including prevalent presence of sand with a little amount of plant detritus, resulted in a fragmentary palynological spectrum only. At the sites Smolno Wielkie and Wojnowo organic deposition began during Younger Dryas. The palynological diagram from the site Wo 3 depicted an image of this interval that it was varied throughout the time (Fig. 5). It remains still disputable to what extent it has resulted from sedimentation and to what extent it reflected changes of climate conditions.

Table 3

Chwalim, site 1. Radiocarbon dating comparison: uncorrected age in years BP and after calibration with the program

OxCal v. 4.2.3 (Bronk Ramsey, Lee 2013); application available on https://c14.arch.ox.ac.uk/oxcal/OxCal.html

\begin{tabular}{|l|c|c|c|c|}
\hline \multicolumn{1}{|c|}{ Bed } & Material & Lab. no. & ${ }^{14}$ C BP* & \multicolumn{2}{|c|}{ Age BC/AD } \\
\cline { 3 - 5 } & charcoal & Gd-1164 & $9,565 \pm 90$ & $\begin{array}{c}9,140(36.4 \%)-8,970 \\
8,947(31.8 \%)-8,797\end{array}$ \\
\hline Basal part of Bed 2 & wood & Gd-1165 & $9,385 \pm 75$ & $8,756-8,564$ \\
\hline Top of bed 2 & charcoal & Bln-1766 & $9,500 \pm 75$ & $\begin{array}{c}9,120(25.8 \%)-9,004 \\
8,218(4.0 \%)-8,896 \\
8,866(37.6 \%)-8,710\end{array}$ \\
\hline Top of bed 2/ very base of bed 2a & & & $9,116(92.5 \%)-8,352$ \\
\hline
\end{tabular}

*According to Schild (1993) 
Table 4

Lubuskie Lake District. The age of deposits from the sites examined with pollen analysis

\begin{tabular}{|c|c|c|c|c|c|c|c|c|}
\hline $\begin{array}{r}\text { Sites } \\
\text { Chronology }\end{array}$ & $\begin{array}{l}\text { Chwalim I/77 } \\
\text { (anal. K.W.) }\end{array}$ & $\begin{array}{c}\text { Chwalim 1/78 } \\
\text { (anal K.W.) }\end{array}$ & $\begin{array}{c}\text { Liny } \\
\text { (anal. I.O-N.) }\end{array}$ & $\begin{array}{l}\text { Pomorsko } \\
\text { (anal. K.T.) }\end{array}$ & $\begin{array}{l}\text { Pomorsko } \\
\text { (anal. I.O-N.) }\end{array}$ & $\begin{array}{c}\text { Smolno Wielkie } \\
\text { SM W-2 } \\
\text { (anal. I.O-N.) }\end{array}$ & $\begin{array}{c}\text { Wojnowo } \\
\text { Wo-2 } \\
\text { (anal. I.O-N.) }\end{array}$ & $\begin{array}{c}\text { Wojnowo } \\
\text { Wo-3 } \\
\text { (anal. I.O-N.) }\end{array}$ \\
\hline Subatlantic & & & & & & & & \\
\hline Subboreal & & & & & & & & \\
\hline Atlantic & & & & & & & & \\
\hline Boreal & & & & & & & & \\
\hline Preboreal & & & & & & & & \\
\hline Younger Dryas & & & & & & & & \\
\hline Allerød & & & & & & & & \\
\hline Pre-Allerød & & & & & & & & \\
\hline
\end{tabular}

Black - uninetrrupted sedimentatioon; dark-grey - interrupted or episodic sedimentation; light-grey episodic sedimentation, chronology ubcertain; I. O-N Iwona Okuniewska-Nowaczyk; K.W - Krystyna Wasylikowa; K.T - Kazimierz Tobolski

\section{Research in the northern part of the Lubuskie Lake District}

Recently, number of Late Glacial archaeological sites have been discovered and examined, mainly during rescue excavations. Palaeoenvironmental research was also carried out for each of those sites.

\section{The Myszecin region}

The most spectacular discoveries were connected with remains of settlements of human groups that colonized the Polish Plain just after ice sheet retreat, namely the Hamburgian culture societies. The site 19 at Myszęcin, where nearly 12,000 flint artefacts were discovered, is currently the richest site of this culture in the whole North European Plain (Kabaciński and Sobkowiak-Tabaka, 2012; Fig. 1). Traces of the Hamburgian hunters' were also discovered at Ośno Lubuskie site 7 (Kabaciński and Sobkowiak-Tabaka, 2010a, b) as well as at Żółwin site 10 (Kabaciński et al., 1998).

The site Myszęcin was located on the north-eastern slope of a small valley created by a left-bank tributary of the Obra River in the vicinity of the Poznań-Berlin highway. Remains of the settlement of the Hamburgian culture societies occurred on the eastern valley slope of a small watercourse that is completely buried at present. During the research 13 accumulations of flint material were found. They encompassed the area of $80-250 \mathrm{~m}^{2}$ and most artefacts were located within the horizon B of the contemporary soil, $50-60 \mathrm{~cm}$ below the surface (Kabaciński and Sobkowiak-Tabaka, 2012).

Both location of the site at an edge and a slope of an expansive valley and presence of depressions without outflow and spots of marshland within the area of the valley close to the site have hinted at the possibility of discovering not only further archaeological sites connected with Late Palaeolithic settlements, but also organic and mineral deposits of the Late Pleistocene, connected with the settlement chronologically. The aforementioned location of the site together with results of rescue excavations were the reason for systematic exploratory works in the area of the Hamburgian site at Myszęcin. As a result, a number of archaeological sites were discovered and excavated. The sites were connected with Late Palaeo- lithic and Mesolithic settlements that played varied functions: from camps of the Świderian culture societies at Wilenko site 16 (Kabaciński and Sobkowiak-Tabaka, 2010a, b; Sobkowiak-Tabaka, 2013), to traces of penetration of this area by the aforementioned societies at Wilenko sites 9 and 10 (Bobrowski, 2010a, b).

Moreover, remains of camps of Mesolithic hunter-gatherers were recorded in the form of dwelling structures and flint artefacts. The sites 13 and 16 at Wilenko were particularly interesting. A limited set of artefacts originating presumably from the Early Mesolithic hearth was discovered at the first site and a relatively large collection of artefacts from Early Mesolithic camp at the second one (Sobkowiak-Tabaka, 2013).

Within the project that was completed this year, multidisciplinary studies were carried out near Myszęcin at the site Wilenko (Fig. 1). First palynological records in the deposits at this site came from the Younger Dryas. In the palynological spectra from both that period and the beginning of the Holocene a charcoal dust was found, which could indicate human activity, because human groups lived at a lakeshore. Because of a sediment gap, the next information about the palaeoenvironment came from the Subboreal Period only and was incomplete. As the palynological dating proves, supported by radiocarbon dating $\left(3985 \pm 35{ }^{14} \mathrm{C} \mathrm{BP}\right.$, Poz43653), a part of the sedimentary sequence from ca. 4000 years ago was preserved (Okuniewska-Nowaczyk, unpubl.).

\section{Ośno Lubuskie}

The site at Ośno Lubuskie was located on a terrace of a former subglacial tunnel valley (Fig. 1). Originally, the valley bottom was mantled with a peat, but it has been exploited to make room for fish ponds. Anthropogenic transformations prevented obtaining untouched deposits for palynological examination.

Rescue excavations connected with construction of a ring road at Ośno Lubuskie turned out that the settlement remains formed a peculiar palimpsest. Individual artefacts were recorded, indicating penetration of this area by the Hamburgian culture societies at the beginning of the Late Glacial. They were covered by settlement traces of the Świ- 
derian culture societies connected with several concentrations of flint material (Younger Dryas/Preboreal period?), followed by traces (two dwelling structures and numerous flint artefacts) of societies living at a cusp of the Boreal and Atlantic periods (Kabaciński and Sobkowiak-Tabaka, 2010a, b)

\section{Lubrza}

An important complement to the image of the Late Glacial settlement at the Lubuskie Lake District was provided by research near Lubrza. It resulted in collection of data regarding settlements of the Federmesser and Świderian culture societies (Fig. 1). Remains of the former societies, presence of which was generally associated with Allerød, was recorded in two accumulations of flint artefacts at Lubrza site 42 (Kabaciński and Sobkowiak-Tabaka, 2011a-c) and one backed-blade at the neighbouring site 8 (Pyżewicz et al., 2008). Results of rescue excavations encouraged to a more detailed exploration of the Late Palaeolithic settlement in this area within a separate research project. This year's research, conducted already within the aforementioned project, has confirmed presence of settlement remains of the Federmesser culture societies also at Lubrza site 10.

Remains of the settlement of the Świderian culture societies were recorded at three sites: at Lubrza, namely 42, 11 (Kabaciński and Sobkowiak-Tabaka, 2011a, b; SobkowiakTabaka, 2011) and 37 (Fig. 6). Remains of the Mesolithic hunters-gatherers were also known from other sites at Lubrza: 10, 11 and 42 (Kabaciński and Sobkowiak-Tabaka, 2011b, c; Sobkowiak-Tabaka, 2013).

The site 42 at Lubrza provided interesting data regarding palaeoenvironment of the Late Vistulian starting from Bølling (Okuniewska-Nowaczyk, 2011a, b). They were characterized by substantial variability of deposits and vegetation succession, different than in a traditional scheme (Fig. 7). It seemed possible that it manifested variability of hydrological and/or climatic conditions. Palynological spectra of Allerød represented a record of not very dense birch-pine forests, followed by pine-birch forests, to display a smaller share of pine at the boundary of gyttja only, thus indicating different character from a conventional bipartition of this period to a younger birch phase and an older pine phase. A lower participation of Pinus sylvestris at the final stage of Allerød could reflect a drop of temperature, indicating the upcoming Younger Dryas.

The above mentioned problems were investigated by multidisciplinary research within a special international project undertaken at the site 10 . Already previous geomorphological and palynological studies corroborated a varying thickness of organic deposits in a small area. Both the first exploratory drilling (Okuniewska-Nowaczyk, 2011b) and the transects performed within the project (Ratajczak-Szczerba et al., 2013) indicated high diversity of thickness of basal peat, starting from none through layers several centimetres thick and up to 80 centimetres. Emergence of such a peat was connected with dead-ice melting during warm climatic oscillations. In light of scientific literature, a thickness of organic deposits set directly on a mineral substrate could be equal from several up to more than 10 centimetres (Więc- kowski, 1966; Nowaczyk, 1994, 2008; Tobolski, 2003; Błaszkiewicz, 2005, and others). In the examined reservoir a peat was up to several dozen centimetres thick, but varied across even closely located cores. Such significant differences in thickness were probably a result of varied micro- relief favourable to emergence of micro- habitats and enabling development of vegetation that required different habitat conditions. A highly varied level of decomposi- tion of a peat might reflect a sedimentatary environment. As far as reconstruction of the settlement processes was concerned, it was of interest to determine both extent of the reservoir in specific periods of Late Vistu- lian and its character i.e. accessibility to Palaeolithic humans. In order to determine this, a detailed geological documentation has being conducted by numerous drillings along more than ten sections across the or- ganic accumulation plain. This was accom- panied by palaeobotanic examination and radiocarbon dating of cores.

\section{DISCUSSION}

Systematic research in the Lubuskie Lake District was not only a multidisciplinary one, as it has been a standard in modern investigations, but also by posed questions and seeked answers, put both by a geoscientist and an archaeologist.

Particularly valuable was the examination of transitions of natural environment in a regional dimension. Despite a high accordance between chronostratigraphy based on correlation with the Greenland oxygen isotope curves and the independent chronologies, a scope of its use in regional contexts, and especially local ones, was very limited. Because of this, for years there have been po- stulates in literature to create a new pan-regional scheme based on results of different environmental markers from respective regions (Litt et al., 2001, 2003; de Klerk, 2004).

The studies in the Lubrza region represented such nature of research. Among the aims of these studies there was reconstruction of the reservoir both in time and in space. Was there a single large lake during Late Vistulian or were there several buried ice blocks of different size, covered with sediments of different thickness and hence melting at a different pace? Is there any cultural diversity of settlement around the reservoir? Can the existence of traces of a society of a given culture at one shore of a water reservoir, and the lack thereof at another be a result of the size of this lake? Was the reservoir at the time of its activity smaller and were the artefacts later under water? To answer these questions, it has been planned after a detailed geomorphological and geological study to conduct a palaeobiological analysis of the cores obtained along the shore of the fossil water reservoir in order to reconstruct vegetation during successive phases of Late Vistulian. A determination of the age of vegetation transitions recorded in biogenic deposits will be corroborated by numerous radiocarbon datings.

Moreover, the site at Lubrza is one of few that provided a possibility for complete reconstruction of natural environment conditions for the entire Late Vistulian and the Holocene, owing to a sequence of organic layers spanning this period. This was indicated not only by palynological analysis, but also by radiocarbon dating of the plant macrofossils (Okuniewska-Nowaczyk, 2011a). A continuation of the re- 
search of that scope was an opportunity to create a benchmark site for that area, which would become a reference point in the studies of transitions of the natural environment during Late Vistulian and early Holocene.

The recognition of these issues was fundamental to the deliberations on the settlements of hunter-gatherer societies, which were highly dependent upon the environmental conditions in which they lived.

\section{CONCLUSIONS}

Because of its location and the nature of the terrain, the study area played an important part in recolonization of the Polish Plain. A detailed analysis of a large number of arte- facts - obtained mainly by means of excavations - and the results of studies of the natural environment transitions, which were extremely significant for the societies of the Late Palaeolithic and Mesolithic, allowed to conclude that the area played a key part in the process of settlement transition during Late Vistulian and early Holocene in this part of western Poland.

\section{Acknowledgements}

The research at Myszęcin and Wilenko was carried out within the project no. 0645/R/H03/ 2009/06 'Multidisciplinary studies as a method of reconstruction of settlement and cultural transitions, western Wielkopolska in the prehistory and the Middle Ages', financed by the Ministry of Science and Higher Education, and completed in 2009-2012 under a leadership of Professor M. Kobusie- wicz. The research near Lubrza (sites 10 and 37) is going to be continued within a research project entitled 'Late Glacial hunter-gatherer societies of the Lubuskie Lake District; chronology, systema- tics and subsistence strategies' (UMO-2011/01/D/HS3/04134), financed by the National Science Centre in 2011-2014, led by I. Sobkowiak-Tabaka.

\section{REFERENCES}

Alexandrowicz S.W., 1980. Aggregations of molluscs in lake chalks of the Lubuskie Region (original: Zespoły malakofauny w kredach jeziornych Ziemi Lubuskiej). In lake chalk and gyttja. National scientific and technological conference - postconference papers, Lubniewice, 8-10.11.1979 (Kreda jeziorna i gytie. Krajowa konferencja naukowo-techniczna - materiały pokonferencyjne, Lubniewice, 8-10.11.1979). Polskie Towarzystwo Przyjaciół Nauk o Ziemi, Oddział Ziemi Lubuskiej, Urząd Wojewódzki in Gorzów Wlkp., Gorzów Wlkp.-Zielona Góra, vol. 2, 24-32 (in Polish).

Alexandrowicz S.W., Nowaczyk B. 1982. Late glacial and Holocene lake sediments at Pomorsko near Sulechów. Questiones Geographicae, 8, 5-17.

Błaszkiewicz M., 2005. Late Glacial and Early Holocene evolution of the lake basin in the Kociewskie Lakeland (Eastern part of Pomeranian Lakeland). Geographical Studies, 201 (in Polish with English summary).

Bobrowski P., 1996. Mesolithic site Wojnowo 3, Kargowa Commune, Zielonogórskie Province (original: Stanowisko mezolityczne Wojnowo stan. 3, gm. Kargowa, woj. zielonogórskie). Wielkopolskie Sprawozdania Archeologiczne 4, 5-22 (in Polish).

Bobrowski P., 2010 a. Flint inventories from Wilenko, site 9 (AUT 47) (original: Materiały krzemienne ze stanowiska Wilenko 9 (AUT 47)). Manuscript in the author's archives (in Polish).

Bobrowski P., 2010 b. Flint inventories from Wilenko, site 10 (AUT 46) (original: Materiały krzemienne ze stanowiska Wilenko 9(AUT 47)). Manuscript in the author's archives (in Polish).

Bobrowski P., Sobkowiak-Tabaka I., Goslar T., Kobusiewicz M., Lityńska-Zając M., Okuniewska-Nowaczyk I., 2013. A work of the Neanderthals or the Late Pleistocene hunters? A wooden object from Wojnowo, Kargowa Commune, Lubuskie Province (original: Dzieło Neandertalczyków czy późnoplejstoceńskich łowców? Drewniany przedmiot z Wojnowa, gm. 


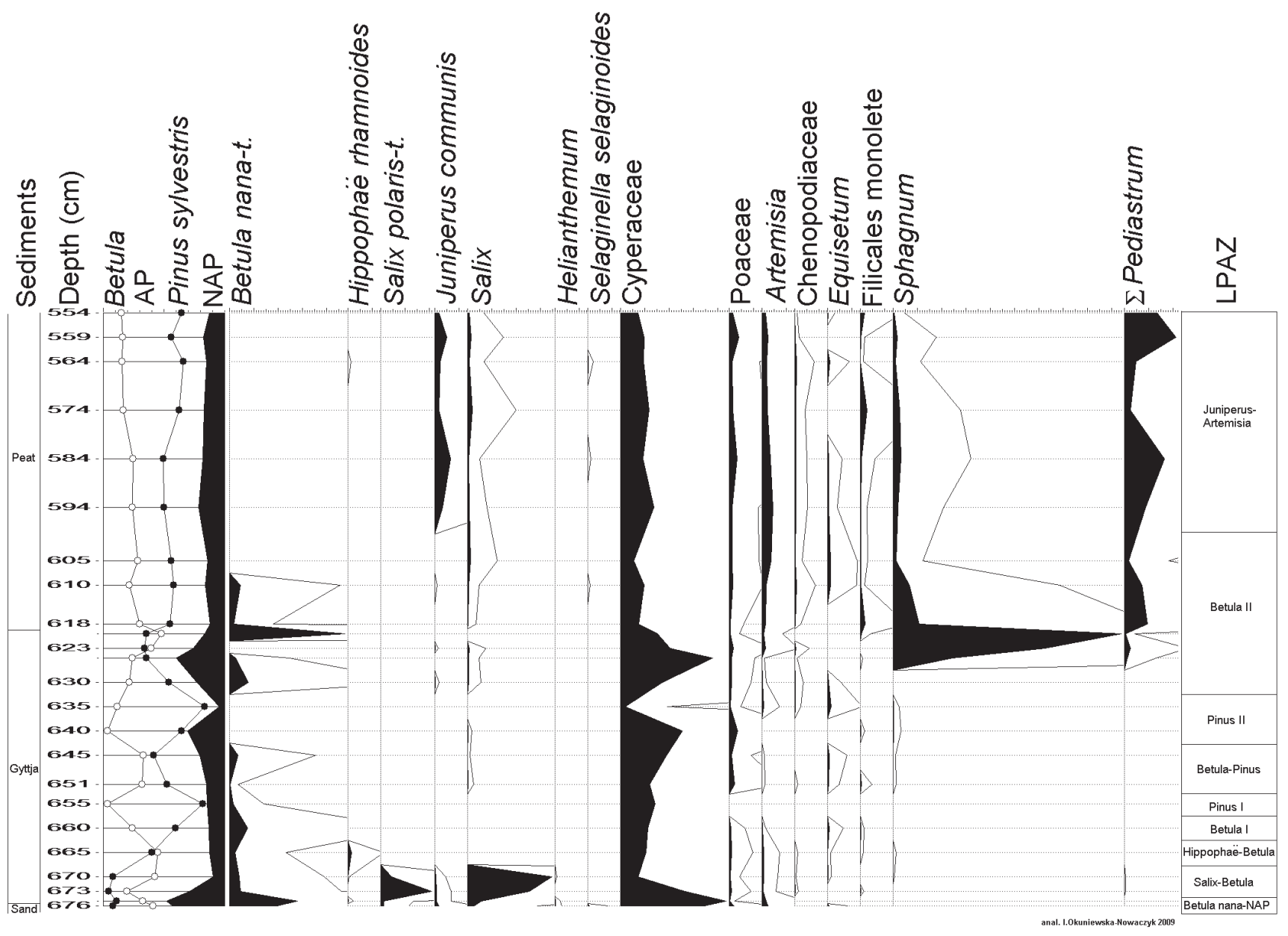

Fig. 6. Lubrza, site 42. Simplified pollen diagram (AP + NAP $=100 \%)$ of Late Glacial after Okuniewska-Nowaczyk (2011a).

Kargowa, woj. lubuskie). Przegląd Archeologiczny 61, 77-91 (in Polish with English summary).

Bower J., Kobusiewicz M., 1988. Late Quaternary Paleogeography of Middle Europe and the Northcentral United States: A Framework for Comparative Studies of Prehistoric Man - Land Relationships. Geoarchaeology. An International Journal 3(2), 117-125.

Bower J., Kobusiewicz, M., 2002. A Comparative Study of Prehistoric Foragers in Europe and North America. Cultural Responses of the End of the Ice Age. The Edwin Mellen Press, New York.

Bronk Ramsey C., Lee S., 2013. Recent and planned development of the program OxCal. Radiocarbon 55, 3-4.

Dzięczkowski A. 1993a. Chapter 9. Analysis of dendrological samples. In: Kobusiewicz, M., Kabaciński, J. (eds.) Chwalim, subboreal hunters-gatherers of the Polish plain, 103-105, Institute of Archaeology and Ethnology, Polish Academy of Sciences, Poznań.

Dzięczkowski A. 1993b. Chapter 10. Molluscs and plant macro-remains. In: Kobusiewicz, M., Kabaciński, J. (eds.) Chwalim, subboreal hunters-gatherers of the Polish plain, 107-110, Institute of Archaeology and Ethnology, Polish Academy of Sciences, Poznań.

Kabaciński J., Krause E., Szamałek K., Winiarska-Kabacińska M., 1998. Zółwin, site 29 (Żółwin, st. 29). In Mazurowski, R. (ed.) Archaeological rescue excavations along the route of the transit gas pipeline (original: Archeologiczne badania ratownicze wzdłuż trasy gazociągu tranzytowego). Ziemia Lubuska,
315-359, Wydawnictwo Poznańskie, Poznań (in Polish).

Kabaciński J., Sobkowiak-Tabaka I., 2010a. Late Palaeolithic settlement. In Kabaciński, J., Sobkowiak-Tabaka, I. (eds.). Materials for Early Prehistory of Western Great Poland. Late Palaeolithic and Mesolithic settlement at the site 7 in Ośno Lubuskie, 17-60, Instytut Archeologii i Etnologii PAN, Poznań (in Polish with English summary).

Kabaciński J., Sobkowiak-Tabaka I., 2010b. Mesolithic settlement. In Kabaciński, J., Sobkowiak-Tabaka, I. (eds.). Materials for Early Prehistory of Western Great Poland. Late Palaeolithic and Mesolithic settlement at the site 7 in Ośno Lubuskie, 63-74, Instytut Archeologii i Etnologii PAN, Poznań (in Polish with English summary).

Kabaciński J., Sobkowiak-Tabaka I., 2011a. Late Palaeolithic (Schyłkowy paleolit). In: Kabaciński, J., Sobkowiak-Tabaka, I. (eds.) Prehistory and Early Medieval settlement in Lubrza (original: Osadnictwo pradziejowe i wczesnośredniowieczne w Lubrzy), 195-262, Instytut Archeologii i Etnologii PAN, Poznań (in Polish).

Kabaciński J., Sobkowiak-Tabaka I., 2011b. Mesolithic (Mezolit). In: Kabaciński, J., Sobkowiak-Tabaka, I. (eds.) Prehistory and Early Medieval settlement in Lubrza (original: Osadnictwo pradziejowe i wczesnośredniowieczne w Lubrzy), 299-324, Instytut Archeologii i Etnologii PAN, Poznań (in Polish).

Kabaciński J., Sobkowiak-Tabaka I., 2011c. Late Palaeolithic and Mesolithic (Schyłkowy paleolit i mezolit). In: Kabaciński, J., Sobkowiak-Tabaka, I. (eds.) Prehistory and Early Medieval settlement in Lubrza (original: Osadnictwo pradziejowe i 
wczesnośredniowieczne w Lubrzy), 21-28, Instytut Archeologii i Etnologii PAN, Poznań (in Polish).

Kabaciński J., Sobkowiak-Tabaka I., 2012. The "Eastern extension" - New data on the Hamburgian in Poland. In: Niekus, M. J. L. Th., Barton, R.N.E., Street, M., Terberger, Th. (eds.) A mind set on flint. Studies in honour of Dick Stapert, 217-234, Barkhuis Publishing, Groningen.

De Klerk P., 2004. Changes in vegetation and environment at the Lateglacial-Holocene transition in Vorpommern (Northeastern Germany). In: Terberger, T., Eriksen, B. V. (eds.) Hunters in changing world. Environment and Archaeology of the Pleistocene-Holocene Transition (ca. 11000-9000 B.C. in Northen Central Europe). Workshop of the U.I.S.P.P. Commission XXXII at Greifswald in Septemper 2002, 27-42, Verlag Marie Leidorf $\mathrm{GmbH}$, Rahden.

Kobusiewicz M., 1973. Problems Concerning Hamburgian Culture in Central Europe. Przegląd Archeologiczny 21, 65-92.

Kobusiewicz M., 1975. The Hamburgian site in Liny, Wolsztyn district. Światowit 34, 213-237 (in Polish with English summary).

Kobusiewicz M., 1996. Status and perspectives of studies on the problems of Late Palaeolithic and Mesolithic in the basin of the middle and lower Odra (original: Stan i perspektywy badań nad problematyką paleolitu późnego i mezolitu w dorzeczu środkowej i dolnej Odry. In: The man and the environment in Lower Nadodrze. Studies on prehistory and early history settlement (Człowiek a środowisko w dolnym Nadodrzu. Badania nad osadnictwem pra- i wczesnodziejowym), 17-26, Instytut Archeologii i Etnologii PAN, Wrocław (in Polish).

Kobusiewicz M., 1999. Hunting-gathering societies of north-western Poland. Poznańskie Towarzystwo Przyjaciół Nauk, Poznań (in Polish with English summary).

Kobusiewicz M., 2008. The first inhabitants of Wielkopolska (original: Pierwsi mieszkańcy Wielkopolski). In: Kobusiewicz, M. (ed.) The prehistory of Wielkopolska. From Stone Age to Medieval Period (original: Pradzieje Wielkopolski. Od epoki kamienia do średniowiecza), 93-120, Instytut Archeologii i Etnologii PAN, Poznań.

Kobusiewicz M., Bobrowski P., Jórdeczka M., in press. Multicultural site Wojnowo 4, Kargowa Commune, Zielona Góra District (Late Palaeolithic, Mesolithic, Lausatian culture) with specialist analyses by I. Okuniewska-Nowaczyk (original: Wielokulturowe stanowisko Wojnowo 4, gmina Kargowa, powiat Zielona Góra (późny paleolit, mezolit, kultura łużycka) z analizami specjalistycznymi I. Okuniewskiej-Nowaczyk) (in Polish with English summary).

Kobusiewicz M., Kabaciński J., 1988. Wojnowo "a" - a Late Pleistocene site with tanged points. Fontes Archeologici Posnaniensis 36 (1987/1988), 1-35 (in Polish with English summary).

Kobusiewicz M., Kabaciński J., 1991. Late Mesolithic Dwelling Object in Pomorsko (Western Poland). Przegląd Archeologiczny $38,5-15$.

Kobusiewicz M., Kabaciński J., 1992. Late Palaeolithic site at Wojnowo, Zielona Góra voivodeship. Fontes Archaeologici Posnanienses 37, 23-46.

Kobusiewicz M., Kabaciński J., 1993. Chwalim. Subboreal HunterGatherers of the Polish Plain. Instytut Archeologii i Etnologii PAN, Poznań.

Kobusiewicz M., Kowalkowski A., Nowaczyk B., OkuniewskaNowaczyk I., 2001. The development of the dunes in Pomorsko. In Guide-Book Jasień-Pomorsko - Late Vistulian and Early Holocene of the region between the Spree and Odra rivers, 1-5 May 2001, Bautzen-Dychów. International Union for Quaternary Research Commission on the Study of the Holocene Subcommission on the Eurosiberian Holocene Spree-
Odra 2001, 17-32.

Kobusiewicz M., Nowaczyk B., Okuniewska-Nowaczyk I., 1987. Late Vistulian Settlement in the Middle Odra Basin. In: Burdukiewicz, J. M., Kobusiewicz, M. (eds.) Late Glacial in Central Europe. Culture and Environment, 165-182, Ossolineum, Wrocław-Warszawa-Kraków-Gdańsk-Lódź159.

Kondracki J., 2009. Regional Geography of Poland (original: Geografia regionalna Polski). Wydawnictwo Naukowe PWN Warszawa (in Polish).

Kowalkowski A., 1977a. A paleopedological investigation of dunes at Pomorsko (West Poland). Questiones Geographicae 4, 4350 .

Kowalkowski A., 1977b. Development dynamics of late Pleistocene and Holocene soil from dune sands at Pomorsko. Roczniki Gleboznawcze 28, 3/4, 19-35 (in Polish with English summary).

Kozarski S., 1995. Deglaciation of northwestern Poland: environmental conditions and geosystem transformation (? $20 \mathrm{ka}>10$ ka BP). Instytut Geografii i Przestrzennego Zagospodarowania PAN, Dokumentacja Geograficzna 1, 1-82 (in Polish with English summary).

Litt T., Brauer A., Goslar T., Merkt J., Bałaga K., Müller H., Ralska-Jasiewiczowa M., Stebich M., Negendank J. F. W., 2001. Correlation and synchronisation of Lateglacial continental sequences in northern central Europe based on annually laminated lacustrine sediments. Quaternary Science Reviews 20, 1233-1249.

Litt T., Schmincke H.-U., Kromer B., 2003. Environmental response to climatic and volcanic events in central Europe during the Weichselian Lateglacial. Quaternary Science Reviews 22, 7-32.

Nowaczyk B., 1974. The genesis and development of a traverse dune in Pomorsko (original: Geneza i rozwój wydmy poprzecznej w Pomorsku). In National Symposium "Development of valley river bottoms of the plain part of the Odra river basin and of inland dunes in the Holocene with reference to the Late Glacial", Wrocław-Poznań 16-21 September 1974, Guidebook (Krajowe Sympozjum "Rozwój den dolinnych rzek niżowej części dorzecza Odry i wydm śródlądowych w holocenie z nawiązaniem do schyłku ostatniego glacjału", Wrocław-Poznań 16-21 września 1974, Przewodnik wycieczki), 40-43 (in Polish).

Nowaczyk B., 1976. The genesis and development of inland dunes in the western part of the Warsaw-Berlin Pradolina in the light of examinations of the structure, granulation and stratigraphy of the deposits which built them. Poznańskie Towarzystwo Przyjaciół Nauk, Prace Komisji Geograficzno-Geologicznej 16, 1-108, Państwowe Wydawnictwo Naukowe, WarszawaPoznań (in Polish with English summary).

Nowaczyk B., 1978. Human role in shaping the dune in Pomorsko near Sulechów (original: Rola człowieka w modelowaniu wydmy w Pomorsku koło Sulechowa). In A guidebook of the field part of the 60th Anniversary of the Polish Geographical Society (Przewodnik części terenowej Zjazdu 60-lecia Polskiego Towarzystwa Geograficznego). Poznań, 85-87 (in Polish).

Nowaczyk B., 1979. The prospects for expansion of lake chalk and calcareous gyttja resources at the area between Pomorsko and Kije (original: Perspektywy powiększenia zasobów kredy jeziornej i gytii wapiennej na obszarze między Pomorskiem a Kijami). In lake chalk and gyttja. National scientific and technological conference - post-conference papers, Lubniewice 8-10.11.1979 (Kreda jeziorna i gytie. Krajowa konferencja naukowo-techniczna - materiały pokonferencyjne, Lubniewice, 8-10 XI 1979). Polskie Towarzystwo Przyjaciół Nauk o Ziemi, Oddział Ziemi Lubuskiej, Urząd Wojewódzki in 
Gorzów Wlkp., Gorzów Wlkp.-Zielona Góra, vol. 1, 86-92 (in Polish).

Nowaczyk B., 1994. Lake age and the problem of disappearence of buried ice blocks based on the example of the Brda outwash near Charzykowy (original: Wiek jezior i problemy zaniku brył pogrzebanego lodu na przykładzie sandru Brdy w okolicy Charzykowy), Acta Universitatis Nicolai Copernici, Geografia 27, 97-110 (in Polish).

Nowaczyk B., 2008. Changes in natural environment in the vicinity of Osłonki (Kujawy, Central Poland) in the light of geological and geomorphological investigations. Folia Quaternaria 78, $7-31$.

Nowaczyk B., Pazdur A., Pazdur M.F., Awsiuk R., 1985. Stratigraphy and conditions of dune development at Pomorsko near Sulechów - new studies. Badania Fizjograficzne nad Polską Zachodnią 35, seria A Geografia Fizyczna, 103-127 (in Polish with English summary).

Okuniewska-Nowaczyk I., 2005. Palynological investigations in SW Great Poland. Fontes Archeologici Posnanienses 41, 9-13 (in Polish with English summary).

Okuniewska-Nowaczyk I., 2011a. Palynological investigations (original: Badania palinologiczne). In: Kabaciński, J., Sobkowiak-Tabaka, I. (eds.). Prehistory and Early Medieval settlement in Lubrza (Osadnictwo pradziejowe i wczesnośredniowieczne w Lubrzy), 263-275, Instytut Archeologii i Etnologii PAN, Poznań (in Polish).

Okuniewska-Nowaczyk I. 2011b. The age of basal peats in Lubrza in the light of palynologiacal and radiocarbon dating (original: Wiek torfów bazalnych w Lubrzy w świetle datowań palinologicznych i radiowęglowych). In: Kabaciński, J., SobkowiakTabaka, I. (eds.). Prehistory and Early Medieval settlement in Lubrza (Osadnictwo pradziejowe i wczesnośredniowieczne w Lubrzy), 279-280, Instytut Archeologii i Etnologii PAN, Poznań (in Polish).

Okuniewska-Nowaczyk I., 2013. Palynological investigations in Wojnowo. Multicultural site Wojnowo 4, Kargowa Commune, Zielona Góra District (Late Palaeolithic, Mesolithic, Lausatian culture) with specialist analyses by I. Okuniewska-Nowaczyk (original: Badania palinologiczne w Wojnowie. Wielokulturowe stanowisko Wojnowo 4, gmina Kargowa, powiat Zielona Góra (późny paleolit, mezolit, kultura łużycka) z analizami specjalistycznymi I. Okuniewskiej-Nowaczyk). Manuscript in the author's archives (in Polish)

Pazdur M.F., Awsiuk R., Bluszcz A., Hałas S., Pazdur A., Walanus A., Zastawny A., 1979. Preliminary results of the study of isotopic fractionation during chemical purification of carbon dioxide for radiocarbon dating. Radiochemical Radioanalytical Letters, 39, 157-168.

Pyżewicz K., Rozbiegalski P., Skorupka P., Dmochowski P., 2008. Two new isolated finds of Late Palaeolithic backed blade from Wielkopolska and Kujawy (original: Dwa nowe odosobnione znaleziska tylczaków schyłkowopaleolitycznych z Wielkopolski i Kujaw). Wielkopolskie Sprawozdania Archeologiczne 9, 13-24 (in Polish).

Ratajczak-Szczerba M., Okuniewska-Nowaczyk I., SobkowiakTabaka I., 2013. The age and development of the lakes in the Jordanów-Niesulice tunnel valley (Lagowskie Lake District the results of preliminary studies at the site in Lubrza (original: Rozwój i wiek jezior rynny jordanowsko-niesulickiej (Pojezierze Łagowskie) - wyniki wstępnych badań na stanowisku w Lubrzy). In Papers of the 4th Workshops of Structural Geomorphology "The structural factor in the development of water and mire ecosystems", Lublin-Chełm, 5-7 June 2013 (Materiały 4. Warsztatów geomorfologii strukturalnej "Czynnik struktury w rozwoju ekosystemów wodno-błotnych", LublinChełm, 5-7 czerwca 2013) (in Polish).
Rust A., 1943. Die alt- und mittelsteinzeitliche Funde von Stelmoor, Karl Wachholtz Verlag, Neumünster.

Schild R., 1993. Chapter 2. Geomorphology and stratigraphy. In: Kobusiewicz, M., Kabaciński, J. (eds.) Chwalim. Subboreal hunters-gatherers of the Polish Plain, 13-18, Institute of Archaeology and Ethnology Polish Academy of Sciences, Poznań.

Sobkowiak-Tabaka I., 2011. Late Palaeolithic societies in the Odra river basin. Instytut Archeologii i Etnologii PAN, Poznań (in Polish with English summary).

Sobkowiak-Tabaka I., 2013. Excavations in the area of the Hamburgian site in Myszęcin (original: Badania rozpoznawcze w rejonie stanowiska kultury hamburskiej w Myszęcinie). Manuscript in the author's archives (in Polish).

Tobolski K., 2003. Peat bogs as seen in the Świecie Region (original: Torfowiska na przykładzie Ziemi Świeckiej). Towarzystwo Przyjaciół Dolnej Wisły, Świecie (in Polish).

Wasylikowa K., 1993. Chapter 8. History of vegetation. In: Kobusiewicz, M., Kabaciński, J. (eds.) Chwalim, subboreal hunters-gatherers of the Polish plain, 91-100, Institute of Archaeology and Ethnology, Polish Academy of Sciences, Poznań,

Więckowski K., 1966. Bottom deposits of Lake Mikołajki. Instytut Geografii Polskiej Akademii Nauk, Prace Geograficzne 57 (in Polish with English summary).

Żynda S., 1963. Commentary to the geomorphological map 1:50000, Sheet N 33-139-B Toporów (original: Objaśnienia do mapy geomorfologicznej 1:50000, Arkusz N 33-139-B Toporów). Dokumentacja Geograficzna PAN, Instytut Geografii, Warszawa, 1-70.

Żynda S., 1967. The geomorphology of the foreland of the end moraine from the Poznan stage in the area of Lubusz Pleistocene Plateau. Poznańskie Towarzystwo Przyjaciół Nauk, Prace Komisji Geograficzno-Geologicznej 8, 1, 1-191 (in Polish with English summary). 